\title{
Tumor-specific histone signature and DNA methylation in multiple myeloma and leukemia cells
}

\author{
V. FOLTANKOVA, S. LEGARTOVA, S. KOZUBEK, E. BARTOVA* \\ Institute of Biophysics, Academy of Sciences of the Czech Republic, Královopolská 135, CZ-612 65, Brno, Czech Republic
}

${ }^{*}$ Correspondence: bartova@ibp.cz

Received November 8, 2011 / Accepted February 9, 2012

\begin{abstract}
Understanding the epigenetics of tumor cells is of clinical significance for the treatment of cancer, and thus, chemists have focused their efforts on the synthesis of new generation of inhibitors of histone deacetylases (HDACs) or methylationspecific enzymes as novel important anti-cancer drugs. Here, we tested whether the histone signature and DNA methylation in multiple myeloma (MM) and leukemia cells is tumor-specific as compared with that in non-malignant lymphoblastoid cells. We observed a distinct histone signature in $c-m y c, M c l-1$, and ribosomal gene loci in MOLP8 MM and K562 leukemia cells, when compared with lymphoblastoid cells. Histone and DNA methylation patterns in MOLP8 cells were partially modified by the clinically promising HDAC inhibitor, vorinostat. In comparison with lymphoblastoid WIL2NS cells, MOLP8 cells and K562 cells were characterized by an absence of the gene silencing marker H3K9me2 in the c-myc and ribosomal genes. However, high levels of $\mathrm{H} 3 \mathrm{~K} 27 \mathrm{me} 3$ were detected in the promoters and coding regions of selected genomic regions in these cells. Treatment by vorinostat increased the level of DNA methylation at the $c$-myc promoter, and this alteration was accompanied by a decrease in c-MYC protein. In MOLP8 cells, vorinostat significantly increased the H3K9 acetylation in the $\mathrm{Mcl}-1$ coding regions and promoter. Both MOLP8 and K562 leukemia cells were characterized by decreased levels of H3K9me2 in the Mcl-1 gene as compared with lymphoblastoid WIL2NS cells. Lower levels of H3K9me1 in the Mcl-1 promoter, however, were specific for MM cells as compared with the other cell types studied. In other MM and leukemia cell lines, COLO677, OPM2, and U937, the ribosomal genes were less prone to epigenetic heterogeneity as compared to the $c$-myc and $\mathrm{Mcl}-1$ proto-oncogenes. Taken together, these data describe both tumor-specific and loci-specific histone signature and DNA methylation profiles.
\end{abstract}

Key words: ChIP, histones, DNA methylation, c-myc, rDNA, Mcl-1

Multiple myeloma (MM) is a plasma cell malignancy characterized by many cytogenetic abnormalities, including $\mathrm{t}(4 ; 14), \mathrm{t}(6 ; 14)$, and $\mathrm{t}(11 ; 14)$ translocations or deletions of the q arm of chromosome 13 [2]. Similarly, leukemia cells typically exhibit tumor-specific cytogenetic changes. For example, the bcr-abl translocation (Ph chromosome), which was discovered as a basic diagnostic marker of chronic

Abbreviations: ChIP - chromatin immunoprecipitation assay; DMEM - Dulbecco's modified Eagle's Medium; Dnmts - DNA methyltransferases; FBS - fetal bovine serum; HDAC - histone deacetylase; HP1 protein - heterochromatin protein 1 ; $M c l-1$ - myeloid cell leukemia sequence 1; MM - multiple myeloma; rDNA, rRNA - ribosomal DNA, RNA; SDS - sodium dodecyl sulphate; VEGF - vascular endothelial growth factor; WLL - white light laser; The Brno nomenclature was used for the histone modifications [1]. myeloid leukemia, and the translocation of the PML and RARa genes are specific for promyelocytic leukemia cells [3]. Cytogenetic aberrations, especially gene translocations, appear as a consequence of inappropriate DNA repair in DNA lesions from distinct genomic regions that can appear in close proximity [4]. Structural cytogenetic aberrations as well as numeric aberrations, such as gene amplifications, are accompanied by changes in both the epigenome and the proteome. Tumor cells are characterized by pronounced changes in DNA methylation or post-translational histone modifications [5]. Global DNA hypomethylation was described first as an epigenetic feature of tumor cells [6]. Moreover, novel biotechnology and molecular biology approaches revealed that the CpG islands in tumor suppressor genes are signifi- 
cantly hypermethylated, and these changes are associated with undesirable silencing of tumor suppressors (summarized by Esteller) [5]. Changes in DNA methylation are also accompanied by changes in the histone signature. For example, histone $\mathrm{H} 4$ lysine 20 trimethylation (H4K20me3) and H4K16 acetylation (H4K16ac) are fundamentally rearranged in many tumor cell types [7]. Aberrant function of the $c-m y c$ protooncogene is responsible for global reduction of histone $\mathrm{H} 3 \mathrm{ac}$ and $\mathrm{H} 4 \mathrm{ac}$, which is accompanied by increased $\mathrm{H} 3 \mathrm{~K} 9 \mathrm{me} 3$ [8, 9]. The $m y c$ proto-oncogene influences chromatin plasticity via regulation of the histone acetyltransferase GCN5. Thus, the $c-m y c$ gene multifunctional contribution to tumorigenesis is evident, especially in relation to transcription and the histone signature. As a result, synthesis of DNA demethylating drugs and histone deacetylase (HDAC) inhibitors seems to be a promising anti-cancer therapeutic strategy. Pharmacological agents directed towards epigenetic-related enzymes are of clinical significance, especially for leukemia and lymphoma treatment [5]. Thus, both basic research and pre-clinical studies are investigating the tumor-specific effects of DNA demethylating agents (e.g., 5-azacytidine or 5-aza-2'deoxycytidine) and HDAC inhibitors (e.g., vorinostat) [10, 11]. Moreover, understanding the details of the epigenetic regulation of oncogenes and tumor suppressor genes will aid in the improvement of epigenetic therapy for tumor cells.

Alongside epigenetic events in tumor cells, the tumorspecific proteome appears as a consequence of structural and numerical aberrations in the genome. For example, chimeric proteins are products of fusion genes, and increased levels of oncoproteins may develop from proto-oncogene amplification. Proper function of apoptosis-related proteins that are responsible for the elimination of unwanted cells from the organism is paramount. In MM cells, the myeloid cell leukemia 1 (Mcl-1) anti-apoptotic protein, which is a member of the Bcl-2 family, exhibits significantly altered function. The $\mathrm{Mcl}-1$ gene is upregulated by vascular endothelial growth factor (VEGF), a protein that typically protects MM cells against apoptosis [12]. Moreover, MM cells are characterized by high levels of the long variant of Mcl-1 protein (Mcl-1L), and in addition, the appearance of the short variant of Mcl-1 (Mcl-1S) is highly specific for this malignancy [13]. Mcl-1 is also required for development and maintenance of B and T lymphocytes [14], demonstrating a link between the function of this protein and B-cell malignancies, such as MM. Due to the facts that Mcl$1 \mathrm{~S}$ appears to be an important diagnostic marker of MM and that alternative splicing of $\mathrm{Mcl}-1$ pre-mRNA is responsible for synthesis of the Mcl-1S protein variant, we were trying to elucidate whether the appearance of Mcl-1S in MM cells is associated with a specific histone signature. In the human genome, many pre-mRNAs are alternatively spliced in a cell-type and tissue-specific manner $[15,16]$. Moreover, recent studies showed that a specific histone signature dictates how splicing proceeds. Luco et al. [17] and Sims et al. [18] suggested that a specific histone area is responsible for recruitment of specific chromatin-binding proteins that are recognized by splicing regulatory factors. For example, depletion of the $\mathrm{CHD} 1$ protein significantly weakens splicing efficiency in vitro. Moreover, efficiency of pre-mRNA splicing was decreased when CHD1 and H3K4me3 levels were reduced [18]. These findings imply that $\mathrm{H} 3 \mathrm{~K} 4 \mathrm{me} 3$ may play an important role in pre-mRNA maturation via the spliceosomal components, which are mediated by the $\mathrm{CHD} 1$ protein.

Based on the data described above, we determined whether the histone signature at selected loci (rDNA, $c-m y c$, and $\mathrm{Mcl}-1$ genes) is specific for MM and leukemia cells and which histone marks could potentially be decisive for pathophysiology of these malignancies. Because the short variant of the Mcl-1 protein is specific to $\mathrm{MM}$, we also investigated the epigenetic area responsible for alternative splicing of $\mathrm{Mcl}-1$ pre-mRNA in MM cells. Moreover, we examined the global effects of the clinically promising HDAC inhibitor drug vorinostat.

\section{Materials and methods}

Cell cultivation. MM MOLP8, COLO677, and OPM2 cells (DSMZ, Braunchweig, Germany) were cultivated in RPMI1640 medium supplemented with $100 \mathrm{U} / \mathrm{ml}$ penicillin, 0.1 $\mathrm{mg} / \mathrm{ml}$ streptomycin, and $20 \%$ fetal bovine serum (FBS; PAN, Germany). Cells were grown at $37^{\circ} \mathrm{C}$ in a humidified atmosphere containing $5 \% \mathrm{CO}_{2}$ and $95 \%$ air. Human leukemia $\mathrm{K} 562$ and U937 cells and lymphoblastoid WIL2NS cells (obtained from European Collection of Cell Cultures, ECACC, UK) were cultivated in a similar manner. WIL2NS cells are described by the European Collection of Cell Cultures (ECACC) as $B$ lymphocytes isolated from the spleen of a Caucasian male with hereditary spherocytic anemia. In our studies, these cells were used as non-malignant controls. In MM MOLP8 cells, we tested the effects of the HDAC inhibitor vorinostat (SAHA, Cayman Chemicals, USA, \#10009929). Twenty-four hours after seeding, MOLP8 cells were treated with $70 \mathrm{nM}$ vorinostat dissolved in ethanol, and then the cells were cultured for an additional $24 \mathrm{~h}$ and harvested for ChIP-PCR and MeDIP-PCR analyses.

Western blots. Western blotting was performed as previously described [19]. Equal amounts of cellular proteins (10 $\mu \mathrm{g})$ were separated with 8-15\% SDS-PAGE and blotted to nitrocellulose membranes. The blots were incubated with the following antibodies: anti-H3K4me2 (\#07-030, UpstateMillipore, USA), anti-H3K4me3 (\#ab8580-25, Abcam, UK), anti-H3K9me1 (\#ab9045-25, Abcam, UK), anti-H3K9me2 (\#07-212, Upstate-Millipore, USA), anti-H3K9me3 (\#07-442, Upstate-Millipore, USA), anti-H3K9ac (\#06-942, Upstate-Millipore, USA), anti-H3K27me3 (\#07-449, Upstate-Millipore, USA), anti-H3K36me3 (\#ab9050, Abcam, UK), anti-Mcl-1 (\#sc-819, Santa Cruz Biotechnology, Santa Cruz, CA, USA), and anti-c-MYC (\#sc-764, Santa Cruz Biotechnology, Santa Cruz, CA, USA). Dilutions were 1:1000-1:2500. The following secondary antibodies were used: peroxidase-conjugated anti-rabbit $\operatorname{IgG}(1: 2000)$ and anti-mouse $\operatorname{IgG}(1: 2000)$. Labeled proteins were visualized with the Amersham ECL Plus western 


\section{A

\begin{tabular}{|l|l|l|l|l|l|l|l|l|l|l|l|l|l}
1 & $\mathrm{~K}$ & $1.5 \mathrm{~K}$ & $2 \mathrm{~K}$ & $2.5 \mathrm{~K}$ & $3 \mathrm{~K}$ & $3.5 \mathrm{~K}$ & $4 \mathrm{~K}$ & $4.5 \mathrm{~K}$ & $5 \mathrm{~K}$ & $5.5 \mathrm{~K}$ & $6 \mathrm{~K}$ & $6.5 \mathrm{~K}$ \\
\hline
\end{tabular}

$\mathrm{Mcl}-1$

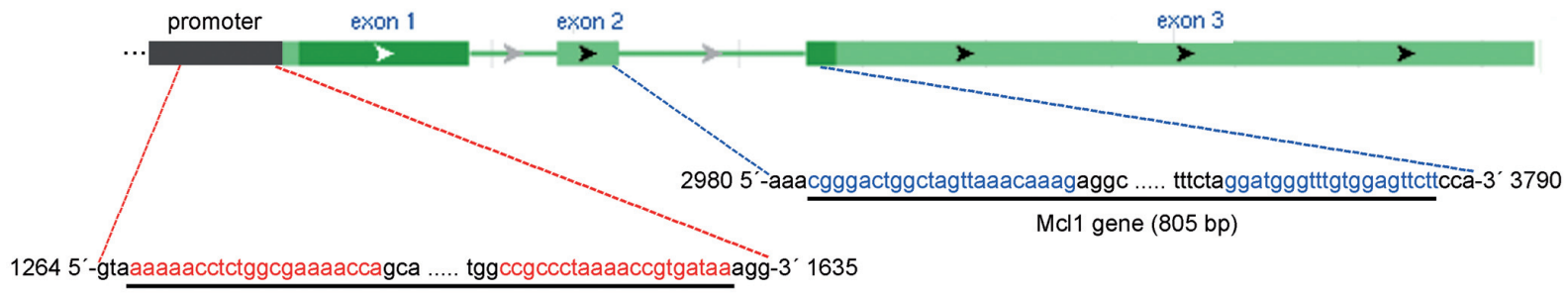

Mcl1 promoter (366 bp)

B

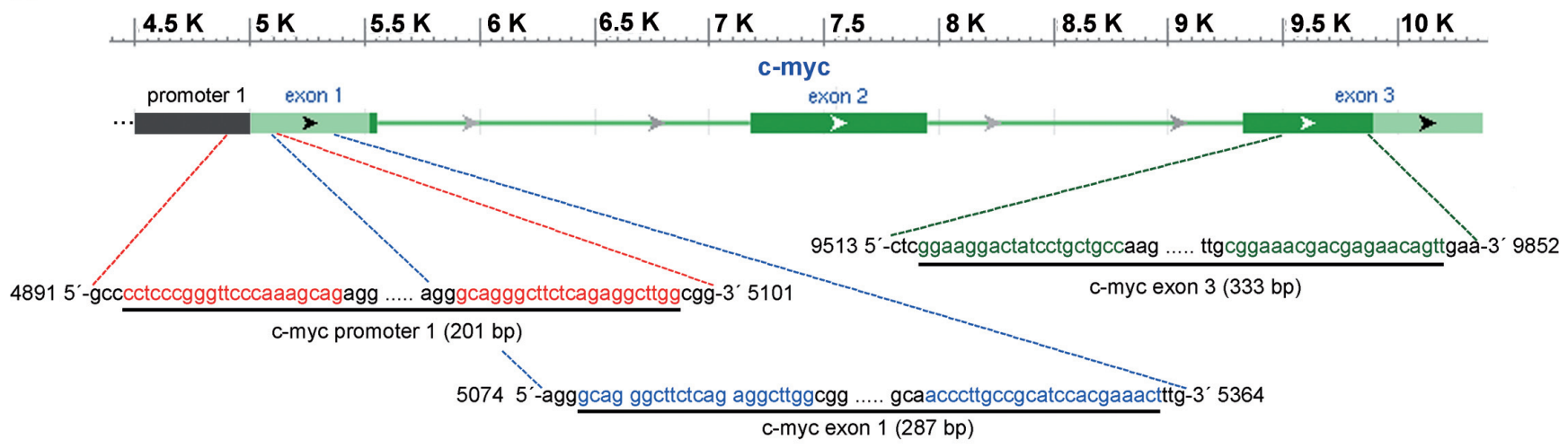

C

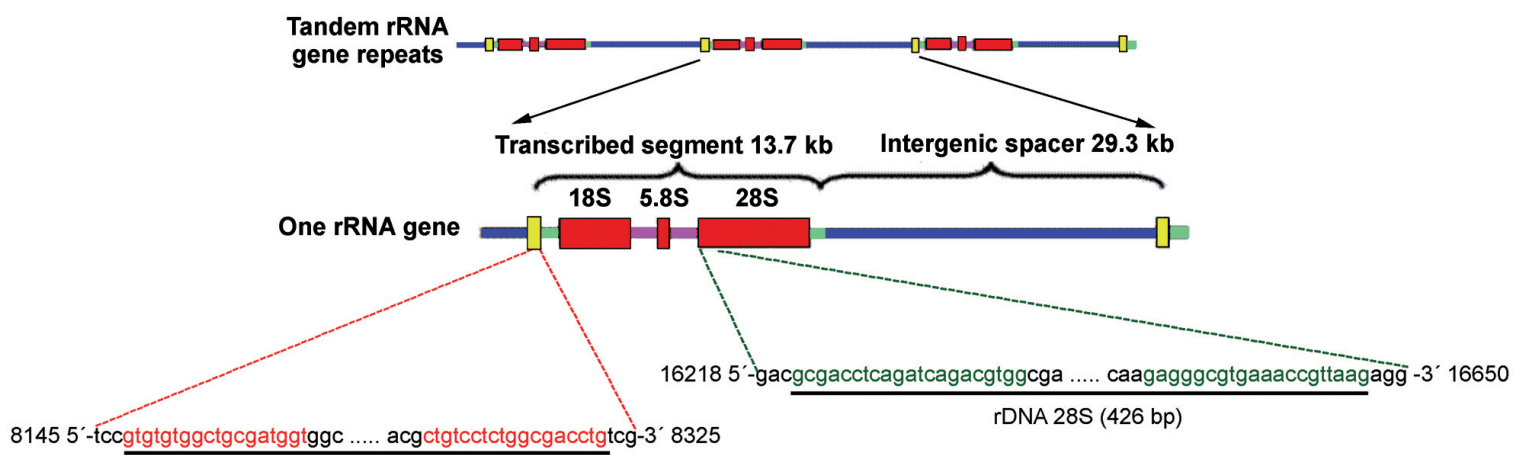

rDNA promoter (183 bp)

Figure 1. Mapping of primers for the $c-m y c, M c l-1$, and ribosomal genes.

Information about genomic regions was acquired from http://www.ncbi.nlm.nih.gov/, and the locations of the primers (red letters for promoters, and blue or green letters for genes) with partial sequences (black letters) of relevant genes are shown. (A) Mcl-1 sequence was obtained from GenBank AF198614.1. Positions 1657 to 6703 of the Mcl-1 gene are shown. (B) The $c$-myc sequence was obtained from NCBI Reference sequence NG_007161.1. Positions 5000 to 10365 of the $c-m y c$ gene are shown. (C) For the ribosomal genes, the sequences of primers were adopted from Financsek et al. [36] and NCBI Reference Sequence: NT_167214.1 REGION: 97129...126696. The coding sequence for the 28S rRNA is located at position 16220 to 21254. Information used for schema of human ribosomal genes was derived from Raška et al. [37].

blotting detection system, and protein level quantification was completed with ImageQuant ${ }^{\mathrm{TM}}$ software (GE Healthcare Life Sciences, Buckinghamshire, UK).

DNA isolation from MOLP8, K562, and WIL2NS cell lines and MeDIP-PCR analyses. DNA was isolated using the QIAamp ${ }^{\circledast}$ DNA Mini kit (QIAGEN; \#51304, Valencia, CA, USA). Isolation was carried out according to the manufacturer's instructions. In brief, cells were pelleted by centrifugation at low speed and disrupted in protease lysis solution. The sample lysates were mixed with $70 \%$ ethanol 
and then applied to a filter, which was then washed to avoid contaminants. Isolated DNA was eluted in nuclease-free water. Purity and concentration of DNA were measured with a NanoDrop 2000A Spectrophotometer (Thermo Scientific, Prague, CZ).

The MeDIP ${ }^{\mathrm{TM}}$ kit (\#mc-green-003, Diagenode, Belgium) was used to study methylated DNA. Approximately $1 \mu \mathrm{g}$ of DNA was diluted in TE buffer, and samples were sonicated $4 \times 10 \mathrm{~s}$ with a UP100H sonicator (Hielscher-Ultrasound Technology, Germany). The MeDIP (methylated DNA immunoprecipitation) procedure was performed according to previously described methods [11]. For immunoprecipitation (IP), the anti-5-MetCyt antibody (the MeDIP kit contains this antibody) was used. Immunoprecipitated DNA was purified using the QIAquick PCR purification kit, and classical PCR was performed with a Peltier thermal cycler DNA engine (BIO-RAD, Prague, CZ). For the $c$-myc gene, PCR was performed as described previously [20]. PCR primers for $\mathrm{Mcl}-1$ gene promoter amplification were previously published [21] and were used with the following PCR program: $95^{\circ} \mathrm{C}$ for $10 \mathrm{~min}$ for DNA denaturation followed by $33 \mathrm{cycles}$ of $94^{\circ} \mathrm{C}$ for $40 \mathrm{~s}, 60^{\circ} \mathrm{C}$ for $60 \mathrm{~s}$, and $72^{\circ} \mathrm{C}$ for $3 \mathrm{~min}$ and then $72^{\circ} \mathrm{C}$ for a $10 \mathrm{~min}$ elongation. The $\mathrm{Mcl}-1$ gene sequence that spanned exons 2 and 3 was amplified with primers published by Schulze-Bergkamen et al. [22] using the following PCR program: $95^{\circ} \mathrm{C}$ for $10 \mathrm{~min}$ followed by 35 cycles of $94^{\circ} \mathrm{C}$ for $15 \mathrm{~s}, 60^{\circ} \mathrm{C}$ for $60 \mathrm{~s}$, and $72^{\circ} \mathrm{C}$ for $3 \mathrm{~min}$ and a final extension of $10 \mathrm{~min}$ at $72^{\circ} \mathrm{C}$. For amplification of the rDNA promoter, the following primers were used: forward 5'-GTGTGTGGCTGCGATGGT-3' and reverse 5'-CAGGTCGCCAGAGGACAG-3'. For amplification of the rDNA encoding 28S rRNA, primers adopted from Santoro and Grummt [23] were used with the following PCR program: $95^{\circ} \mathrm{C}$ for $1 \mathrm{~min}$ for DNA denaturation followed by 28 cycles of $94^{\circ} \mathrm{C}$ for $30 \mathrm{~s}, 64^{\circ} \mathrm{C}$ for $40 \mathrm{~s}$, and $72^{\circ} \mathrm{C}$ for $40 \mathrm{~s}$ and then elongation for 5 minutes at $72^{\circ} \mathrm{C}$. All primers used for MeDIP-PCR analyses were also used for ChIP-PCR studies, and the positions of the individual primers are shown in Fig. 1.

Chromatin immunoprecipitation assay (ChIP). ChIP was performed according to the manufacturers' instructions (\#17-295, ChIP Assay Kit, Millipore, Temecula, CA, USA). A detailed description was published previously [11, 24]. For analysis, we used equal amounts of cells $\left(1 \times 10^{6}\right)$. Cells were enumerated with the automated cell counter TC10 ${ }^{\mathrm{TM}}$ (BioRad, Prague, CZ). Formaldehyde (at a final concentration of $1 \%$ ) was added directly to the cell culture in order to crosslink the histones and the DNA. The cells were then washed with phosphate buffered saline (PBS) containing protease inhibitor cocktail (1 mM phenylmethylsulfonyl fluoride [PMSF], $1 \mu \mathrm{g} / \mathrm{ml}$ aprotinin, and $1 \mu \mathrm{g} / \mathrm{ml}$ pepstatin A). Cell lysates were obtained by cell incubation with sodium dodecyl sulphate (SDS) lysis buffer for $10 \mathrm{~min}$ on ice, and sonication was used in order to produce DNA fragmentation of 200 to $1000 \mathrm{bp}$. In the next step, the histone-DNA complexes were centrifuged and diluted in ChIP dilution buffer. Part of the supernatant was stored at $4^{\circ} \mathrm{C}$ until DNA isolation, and this sample was

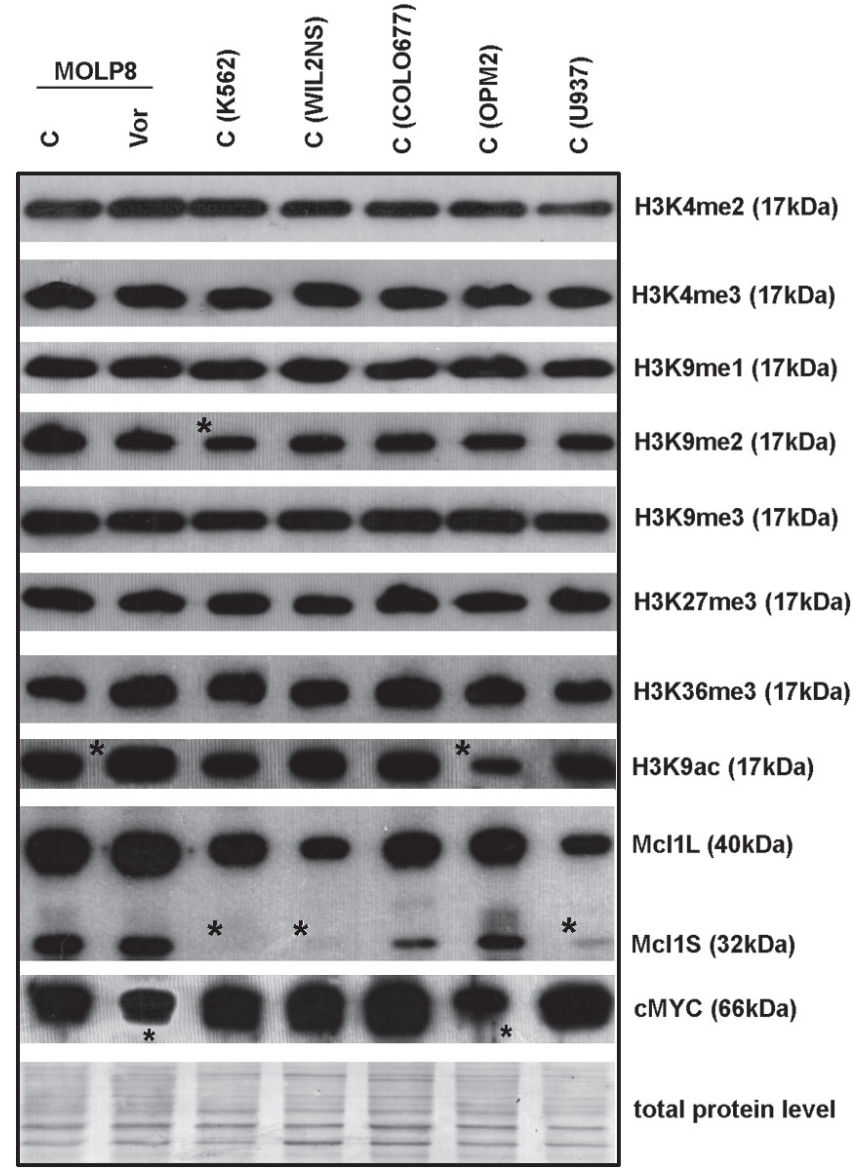

Figure 2. Western blot analysis of selected histone marks and proteins in MM, leukemia, and lymphoblastoid cells. The following antibodies were used for western blot: anti-H3K4me2, anti-H3K4me3, anti-H3K9me1, anti-H3K9me2, anti-H3K9me3, anti-H3K27me3, anti-H3K36me3, antiH3K9ac, anti-Mcl-1, and anti-c-myc. For normalization of the western blot fragments densities, we used total protein levels. Western blot analyses were performed in leukemia K562 or U937 cells and MM MOLP8, OPM2, and COLO677 cells. As a control population, WIL2NS cells were used. " $\mathrm{C}$ " indicates control cell population without treatment. "Vor" indicates vorinostat treatment.

considered as input material. The remaining supernatant was immunoprecipitated using $5 \mu \mathrm{l}$ of the appropriate antibody (see western blot description). As negative controls, we used samples immunoprecipitated with anti-rabbit IgG (\#A-4914, whole molecule, Sigma-Aldrich, Prague, CZ). After overnight immunoprecipitation at $4^{\circ} \mathrm{C}$, the histone-DNA immunocomplexes were incubated for $2 \mathrm{~h}$ at $4^{\circ} \mathrm{C}$ with protein A agarose beads and then washed according to a previously published procedure [24]. We used washing buffers from the ChIP Assay Kit (\#17-295, Millipore, Temecula, CA, USA), and then eluted the proteins in $0.1 \mathrm{M} \mathrm{NaHCO}_{3}$ with $1 \% \mathrm{SDS}$. HistoneDNA crosslinks were released by sample incubation at $65^{\circ} \mathrm{C}$ for $6 \mathrm{~h}$ or overnight. Then, the ChIP-DNA was isolated by QIAamp ${ }^{\circledast}$ DNA Mini kit (\#51304, QIAGEN, Valencia, CA, USA) and used for PCR. 
Immunofluorescence and confocal microscopy. Immunofluorescence was performed according to Bártová et al. [19]. We used an antibody against fibrillarin (\#5821, Abcam, UK), anti-H3K9me2 (\#07-212, Upstate-Millipore, USA), and anti-H3K27me3 (\#07-449, Upstate-Millipore, USA). Images were acquired with the confocal microscope Leica TSC SP5 X (Leica Microsystems, Mannheim, Germany), which was equipped with white light (WLL, 470-670 $\mathrm{nm}$ in 1-nm increments), argon (488 nm), and UV (405 and $355 \mathrm{~nm}$ ) lasers. For conventional confocal scanning, we used the WLL (470-670 $\mathrm{nm}$ ), bidirectional scanning mode with a speed of $400 \mathrm{~Hz}$. The pixel size was $240.5 \mathrm{~nm} \times 240.5 \mathrm{~nm}$, magnification was $63 \times$, and the N.A. was 1.4.

\section{Results}

We studied the histone signature, including $\mathrm{H} 3 \mathrm{~K} 4 \mathrm{me} 2$, H3K4me3, H3K9me1, H3K9me2, H3K9me3, H3K27me3, $\mathrm{H} 3 \mathrm{~K} 36 \mathrm{me} 3$, and $\mathrm{H} 3 \mathrm{~K} 9 \mathrm{ac}$, in the genome as a whole as well as in selected genomic regions of the $c$-myc gene, the $M c l-1$ gene, and ribosomal genes in MM MOLP8 cells and leukemia K562 cells. Additionally, we tested selected histone marks in MM COLO677 and OPM2 cells as well as in leukemia U937 cells. Data were compared with the histone signature of given genomic regions in non-malignant WIL2NS cells. We also examined the effects of vorinostat on the histone signature and DNA methylation levels in MM cells.

Global levels of epigenetic histone modifications. Analysis of the global levels of H3K4me2, H3K4me3, H3K9me1, H3K9me2, H3K9me3, H3K27me3, H3K36me3, and H3K9ac by western blot analysis showed the global stability of many histone marks in various MM and leukemia cell lines (Fig. 2). One exception was $\mathrm{H} 3 \mathrm{~K} 9 \mathrm{ac}$, which was increased following vorinostat treatment in MOLP8 cells and was significantly lower in OPM2 cells when compared with non-malignant WIL2NS cells (Fig. 2, asterisks). In addition, global H3K9me2 was lower in K562 cells when compared with other cell types studied (Fig. 2, asterisk). The levels of the other histone marks examined were relatively similar in all three cell types studied (Fig. 2).

Histone signature in the c-myc gene and ribosomal gene regions.

H3K4me2. In comparison with non-malignant WIL2NS cells, H3K4me2 was increased in the $c-m y c$ promoter $\mathrm{P} 1$ and rDNA encoding 28S rRNA in K562 cells or in the rDNA promoter in MOLP8 and K562 cells (Fig. 3A, red asterisks). When MOLP8 cells were treated with the HDAC inhibitor vorinostat, increased $\mathrm{H} 3 \mathrm{~K} 4 \mathrm{me} 2$ in the chromatin of the rDNA promoter and rDNA encoding $28 \mathrm{~S}$ rRNA or the $c-m y c$ promoter $\mathrm{P} 1$ was observed (Fig. 3A, blue asterisks). The levels of H3K4me2 in exon 1 and exon 3 of the $c-m y c$ gene in malignant cells were similar to those in non-malignant lymphoblastoid WIL2NS cells (Fig. 3A).

H3K4me3. In comparison with WIL2NS cells, H3K4me3 was reduced in the rDNA promoter and $c-m y c$ promoter of
MOLP8 cells. Vorinostat treatment increased H3K4me3 in the region encoding $28 \mathrm{~S}$ rRNA and in the $c$-myc promoter in MOLP8 cells (Fig. 3B). In comparison with WIL2NS cells, K562 cells exhibited an increased level of H3K4me3 in the promoter and coding regions of ribosomal genes (Fig. 3B).

H3K9me1. Compared to non-malignant WIL2NS cells, decreased levels of $\mathrm{H} 3 \mathrm{~K} 9 \mathrm{me} 1$ were observed in the $c$-myc promoter, but increased $\mathrm{H} 3 \mathrm{~K} 9 \mathrm{me} 1$ was in $c$-myc exon 1 in $\mathrm{K} 562$ cells (Fig. 3C). Similarly, the $c-m y c$ promoter and exon 3 in MOLP8 cells was characterized by lower levels of $\mathrm{H} 3 \mathrm{~K} 9 \mathrm{mel}$ compared to the promoter and exon 3 in WIL2NS cells. However, vorinostat treatment increased H3K9me1 levels substantially in the $c-m y c$ gene promoter and slightly in $c$-myc exon 3. Thus, following vorinostat treatment, $\mathrm{H} 3 \mathrm{~K} 9 \mathrm{me} 1$ levels in the $c-m y c$ gene in MOLP8 cells were comparable to those observed in control WIL2NS cells (Fig. 3C). Interestingly, $\mathrm{H} 3 \mathrm{~K} 9 \mathrm{me} 1$ was barely detected in the ribosomal genes in MOLP8 and WIL2NS cells, whereas higher level of H3K9me1 was observed in the rDNA promoter and rDNA encoding the 28S rRNA in K562 cells (Fig. 3C).

H3K9me2. H3K9me2 was not detected in either MM MOLP8 or leukemia K562 cells in any of the regions analyzed for ribosomal genes or in the $c-m y c$ proto-oncogene (Fig. 3D). This finding was in contrast with the appearance of $\mathrm{H} 3 \mathrm{~K} 9 \mathrm{me} 2$ in the promoter, exon 1 , and exon 3 of the $c$-myc gene in lymphoid WIL2NS cells. In MM cells following vorinostat treatment, H3K9me2 was detected in $c$-myc exon 3 (Fig. 3D). Taken together, in MM and leukemia cells, a very low level of gene silencing marker, H3K9me2, was found. Moreover, H3K9me2 was substituted by a high level of another repression marker, H3K27me3 (compare panel D with panel F in Fig. 3; $\mathrm{H} 3 \mathrm{~K} 27 \mathrm{me} 3$ is described below).

H3K9me3. In comparison with other histone marks, relatively low levels of $\mathrm{H} 3 \mathrm{~K} 9 \mathrm{me} 3$ were found in the selected regions of the ribosomal genes in all cell types tested (Fig. 3E). Specifically, no H3K9me3 was detected in ribosomal genes in MM MOLP8 cells. In contrast to K562 cells, abundant $\mathrm{H} 3 \mathrm{~K} 9 \mathrm{me} 3$ was detected in the $c$-myc proto-oncogene in MOLP8 and WIL2NS cells. Vorinostat treatment reduced the levels of this histone mark in the $c$-myc coding sequences in MOLP8 cells (Fig. 3E).

H3K27me3. Relatively high levels of H3K27me3 were observed in MOLP8 cells as compared to WIL2NS cells (Fig. 2). Significantly higher levels of $\mathrm{H} 3 \mathrm{~K} 27 \mathrm{me} 3$ were found in rDNA promoter, $28 \mathrm{~S}$ rDNA and the $c-m y c$ promoter $\mathrm{P} 1$, exon 1 , and exon 3 in MOLP8 cells when compared with WIL2NS cells (Fig. 3F). Vorinostat treatment reduced the level of H3K27me3 in the promoter of the $c-m y c$ gene (Fig. $3 \mathrm{~F}$ ). In comparison with WIL2NS cells, K562 cells were characterized by increased level of $\mathrm{H} 3 \mathrm{~K} 27 \mathrm{me} 3$ in rDNA promoter, $28 \mathrm{~S}$ rDNA and the c-myc exon 3 (Fig. 3F).

H3K36me3. In comparison with WIL2NS cells, H3K36me3 was increased in the P1 promoter of the $c-m y c$ gene in MOLP8 cells (Fig. 3G). After vorinostat treatment, H3K36me3 was significantly increased in the rDNA encoding $28 \mathrm{~S}$ rRNA, $c$ - 


\section{Histone signature of rDNA genes and c-myc in MOLP8, K562 and WIL2NS cells}
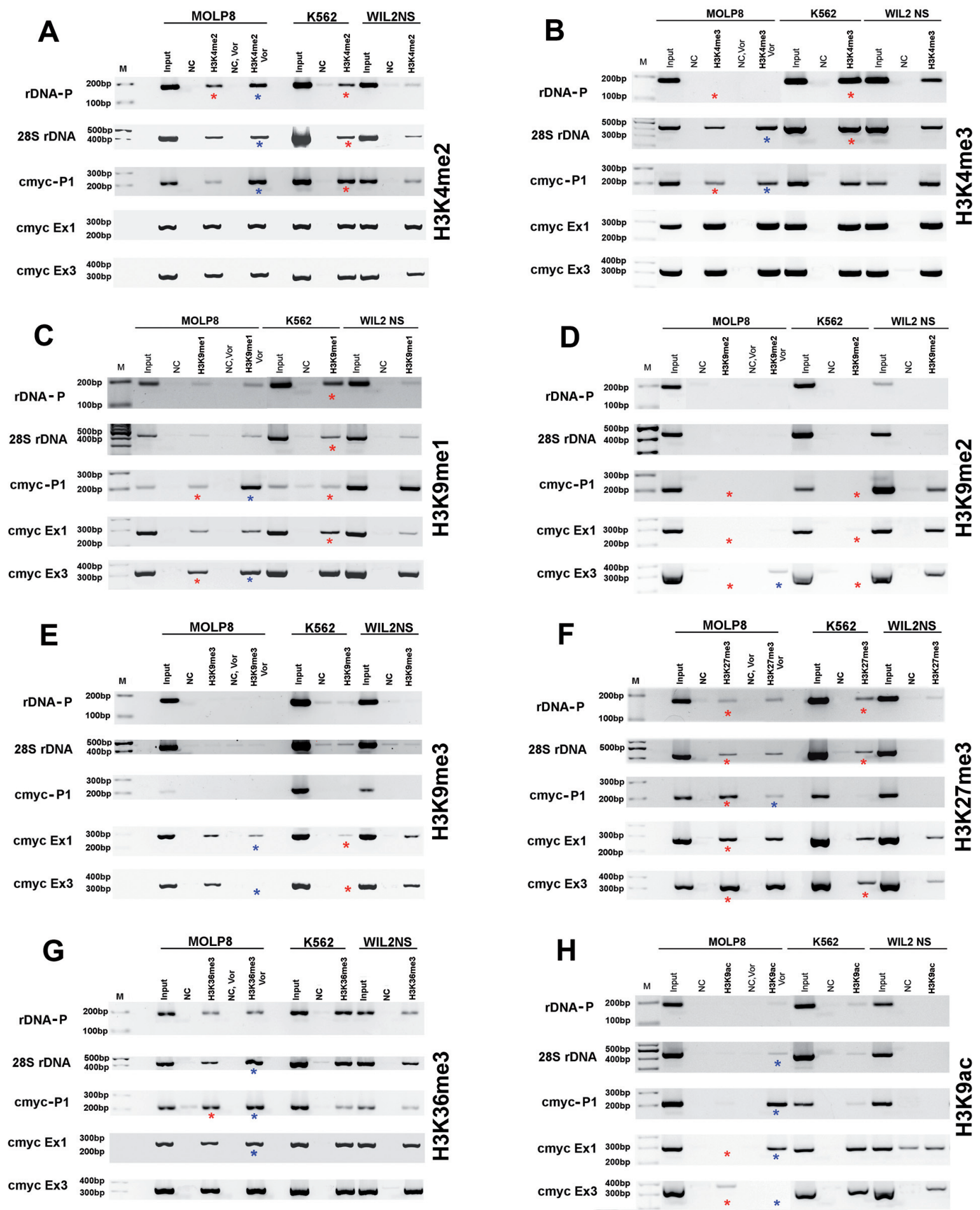

Figure 3. Histone signature in ribosomal genes and the c-myc proto-oncogene. In MM MOLP8, leukemia K562, and lymphoblastoid WIL2NS cells, ChIPPCR analyses revealed specific distinctions in levels of (A) H3K4me2, (B) H3K4me3, (C) H3K9me1, (D) H3K9me2, (E) H3K9me3, (F) H3K27me3, (G) H3K36me3, and (H) H3K9ac. Red asterisks indicate the significant differences between the histone levels in each cell line as compared to control WIL2NS cells. Blue asterisks indicate significant differences in the levels of histone marks between control non-treated MOLP8 cells and vorinostat-treated MOLP8 cells. " $M$ " indicates DNA marker. "Vor" indicates vorinostat treatment. "NC" indicates negative control (non-specific IgG was added). "P" denotes the promoter, and "Ex" denotes the exons. 

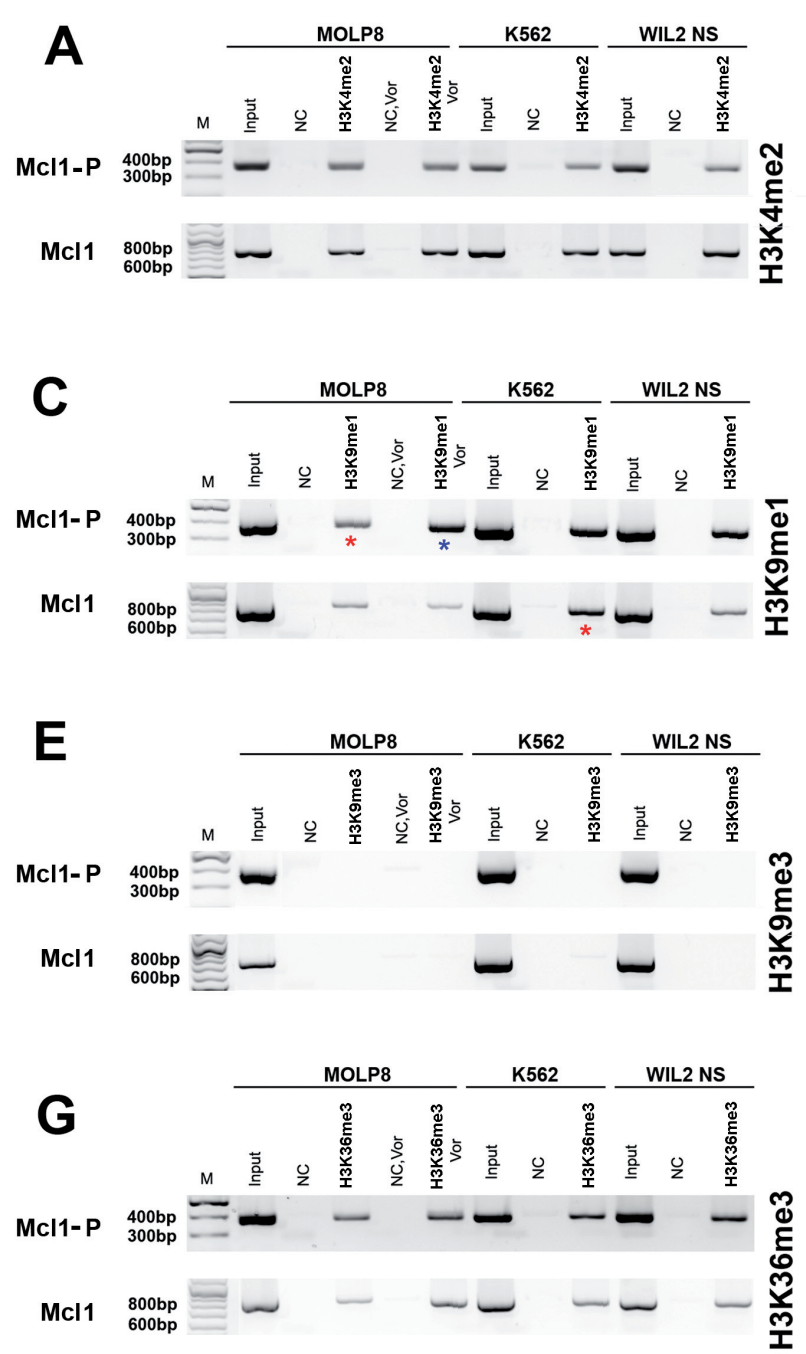
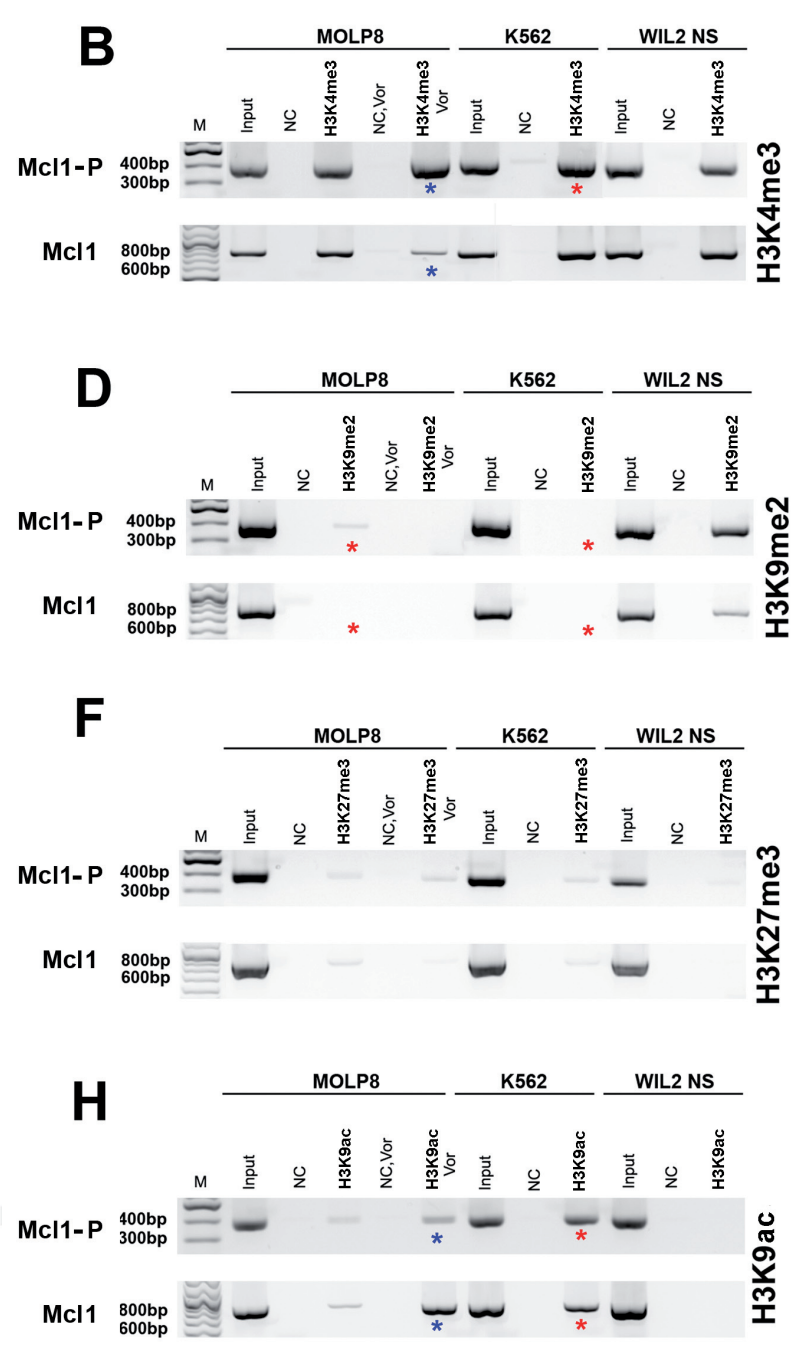

Figure 4. Histone signature at the $\mathrm{Mcl}-1$ locus. The following histone marks were examined in both the promoter and coding regions of the $\mathrm{Mcl}-1$ gene: (A) H3K4me2, (B) H3K4me3, (C) H3K9me1, (D) H3K9me2, (E) H3K9me3, (F) H3K27me3, (G) H3K36me3, and (H) H3K9ac. "M" indicates DNA marker. "Vor" indicates vorinostat treatment. "NC" indicates the negative control (non-specific IgG was added). "P" indicates the promoter.

$m y c$ promoter, and $c-m y c$ exon 1 as compared to non-treated MOLP8 cells (Fig. 3G).

H3K9 acetylation. Compared to leukemia K562 cells, MOLP8 cells exhibited a very low level of H3K9ac in the c-myc proto-oncogene coding regions (Fig. $3 \mathrm{H}$ ). Vorinostat treatment resulted in an increase in $\mathrm{H} 3 \mathrm{~K} 9 \mathrm{ac}$ in the rDNA encoding $28 \mathrm{~S}$ rRNA as well as in the P1 promoter and exon 1 of the $c$ - $m y c$ gene (Fig. $3 \mathrm{H}$ ). These experiments confirmed a hyperacetylation effect of the HDAC inhibitor vorinostat, although, vorinostat treatment decreased $\mathrm{H} 3 \mathrm{~K} 9 \mathrm{ac}$ in the $c-m y c$ exon 3 (Fig. $3 \mathrm{H}$ ).

Epigenetics of the Mcl-1 gene in MM and leukemia cells. The $\mathrm{Mcl}-1$ gene encodes an anti-apoptotic protein $\mathrm{Mcl}-1$, which is a member of the Bcl-2 family. Two well-known isoforms of this protein have been found: a longer form (isoform 1 or long variant $\mathrm{L}$ ) and a shorter gene product (isoform 2 or short vari- ant S) (Fig. 1A shows $\mathrm{Mcl}-1$ gene map). Alternative splicing is responsible for mentioned Mcl-1 variants. Isoform 1 is involved in inhibition of apoptosis, while the alternatively spliced shorter gene products (isoform 2 and isoform 3 ) exhibit a proapoptotic function (http://www.ncbi.nlm.nih.gov/sites).

In comparison with WIL2NS cells, MOLP8 and leukemia K562 cells were characterized by similar levels of H3K4me2 (Fig. 4A). However, in K562 cells, increased H3K4me3 at the $\mathrm{Mcl}-1$ promoter (Fig. 4B) and increased $\mathrm{H} 3 \mathrm{~K} 9 \mathrm{mel}$ in the $\mathrm{Mcl}-1$ coding region were found (Fig. 4C). In MOLP8 and leukemia K562 cells, H3K9me2 was reduced (Fig. 4D). Histone modifications, including H3K9me3 (Fig. 4E), H3K27me3 (Fig. 4F), and H3K36me3 (Fig. 4G) were identical in all cell types studied. In K562 cells, H3K9ac was increased in the promoter and coding regions of the $\mathrm{Mcl}-1$ gene in comparison with control WIL2NS cells (Fig. 4H). 
By western blot analysis, we observed the appearance of the shorter variant (Mcl-1S) in all MM cell lines studied but not in leukemia K562 or WIL2NS cells (Fig. 2, asterisks). Based on this finding, we examined the potential correlation between the appearance of $\mathrm{Mcl}-1 \mathrm{~S}$ and a specific histone signature. With regard to the histone signature of the $\mathrm{Mcl}-1$ gene, MOLP8 cells were characterized by low levels of $\mathrm{H} 3 \mathrm{~K} 9 \mathrm{me} 1$ and $\mathrm{H} 3 \mathrm{~K} 9 \mathrm{me} 2$ as compared to lymphoblastoid WIL2NS cells (Fig. 4C and D). The other tested histone marks were not significantly altered in MM cells (Fig. 4F, G, and H). Vorinostat treatment increased $\mathrm{H} 3 \mathrm{~K} 9 \mathrm{mel}$ in the $\mathrm{Mcl}-1$ promoter (Fig. 4C) and enhanced $\mathrm{H} 3 \mathrm{~K} 9 \mathrm{ac}$ in the $\mathrm{Mcl}-1$ promoter and coding regions in MOLP8 cells (Fig. 4H). Based on these results, we examined whether a specific combination of histone marks may be responsible for $M c l-1$ alternative splicing, in a manner similar to that observed for other loci by Luco et al. and Sims et al. [17, 18]. The influence of a specific histone signature on $\mathrm{Mcl}-1$ alternative splicing was ruled out by the observation that no changes in the Mcl-1S variant were detected after vorinostat treatment (Fig. 2). Thus, expected disappearance of Mcl-1S fragment was not found despite the fact that vorinostat increased H3K9me1 in the $\mathrm{Mcl}-1$ promoter to the similar level as observed in WIL2NS cells (Fig. 4C), characterized by absence of Mcl-1S (Fig. 2).

DNA methylation. DNA methylation was studied by MeDIP analysis. In comparison with WIL2NS cells, K562 cells were characterized by a reduced level of DNA methylation at the rDNA promoter, and both MOLP8 and K562 cells had a reduced level of DNA methylation in the rDNA coding region (Fig. 5A and quantification in Fig. 5B). Vorinostat treatment had no significant effect on DNA methylation at the ribosomal genes in MM cells.

In comparison with WIL2NS cells, DNA methylation was lower in the $c-m y c$ exon 1 in MOLP8 cells, whereas, surprisingly, DNA methylation was increased in the $c-m y c$ promoter following vorinostat treatment (Fig. 5A). Additionally, an increase in DNA methylation was observed in exon 1 of the $c$-myc gene in MM cells after vorinostat treatment (Fig. 5A and quantification in B). This epigenetic event was accompanied by reduced c-myc protein levels (Fig. 2, asterisk). Thus, DNA methylation events are likely responsible for the c-myc downregulation.

Analysis of DNA methylation in the $\mathrm{Mcl}-1$ gene revealed identical levels of this epigenetic mark in WILL2NS and MOLP8 cells, although very high levels of DNA methylation were observed in the promoter of the $\mathrm{Mcl}-1$ gene in $\mathrm{K} 562$ cells (for the best explanation, see quantification in Fig. 5B). In MOLP8 cells, vorinostat treatment reduced DNA methylation in both the $\mathrm{Mcl}-1$ promoter and coding region (Fig. 5A and $\mathrm{B})$.

Histone signature in MM COLO677, OPM2 cells, and leukemia U937 cell lines. We tested also whether selected histone marks are altered in several other cell lines. For such experiments, we cultivated MM COLO677, OPM2, and leukemia U937 cells. By ChIP-PCR, we analyzed H3K9me1, H3K9me2, and H3K27me3 (Fig. 6A-C) in selected genomic

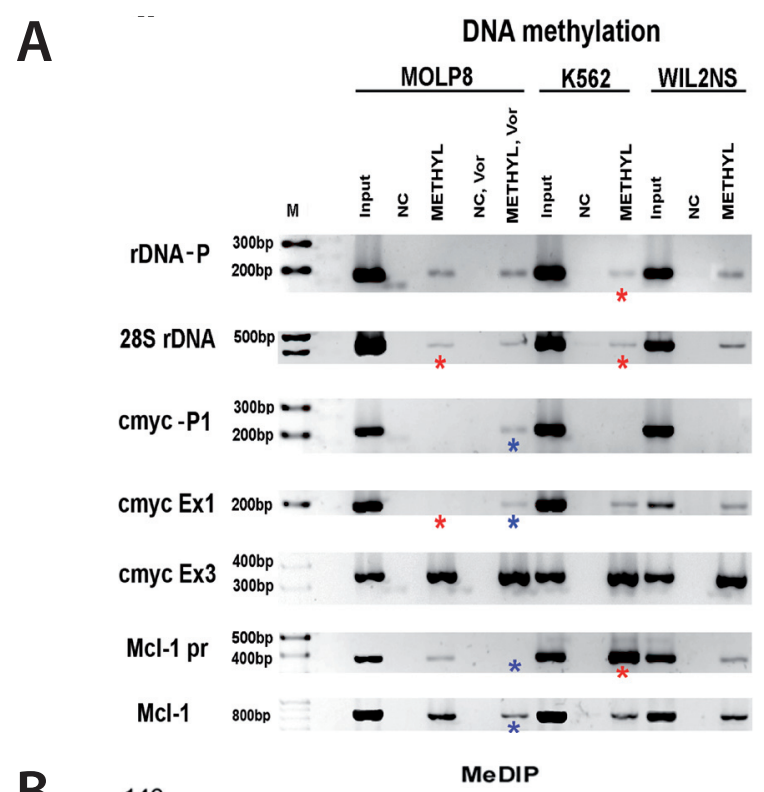

B
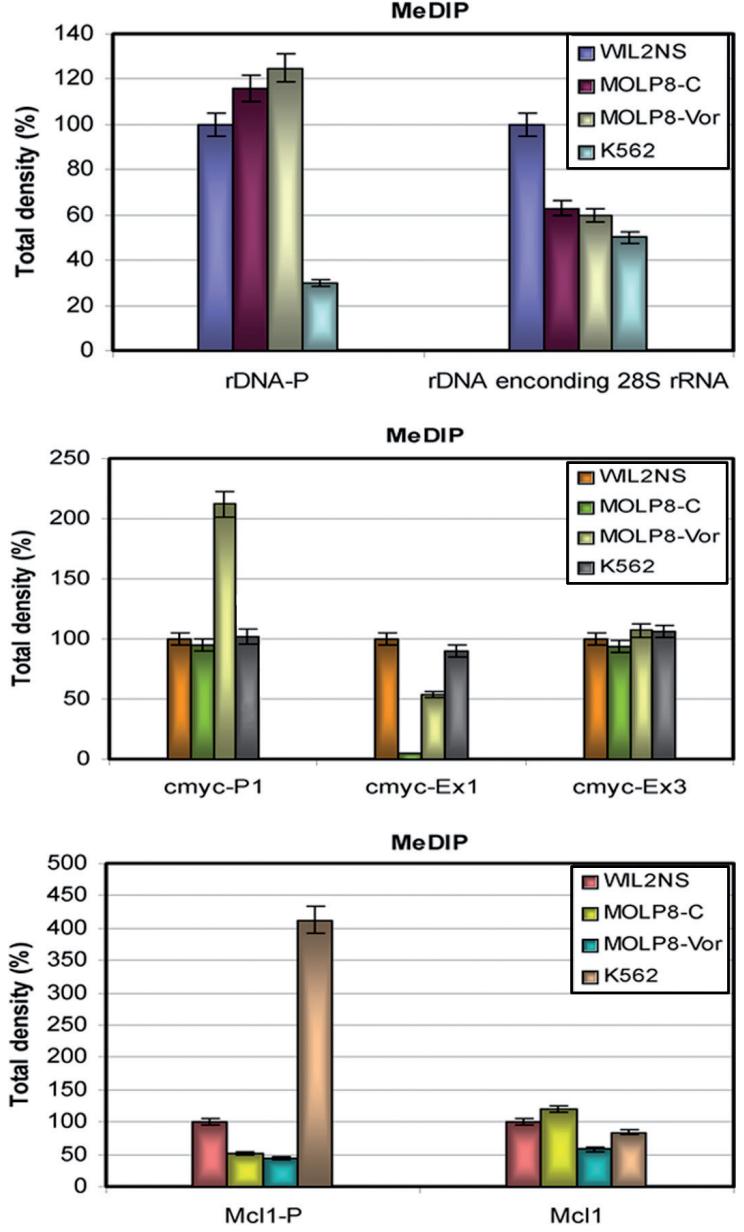

Figure 5. DNA methylation levels in the $c$-myc proto-oncogene, $M c l-1$ gene, and ribosomal genes in MM, leukemia, and lymphoblastoid cells. (A) MeDIP-PCR analysis showed distinct DNA methylation profiles in selected genomic regions. (B) Quantification of the results shown in Fig. $5 A$. "M" indicates DNA marker. "Vor" indicates vorinostat treatment. "P" indicates the promoter, and "Ex" indicates the exons. 

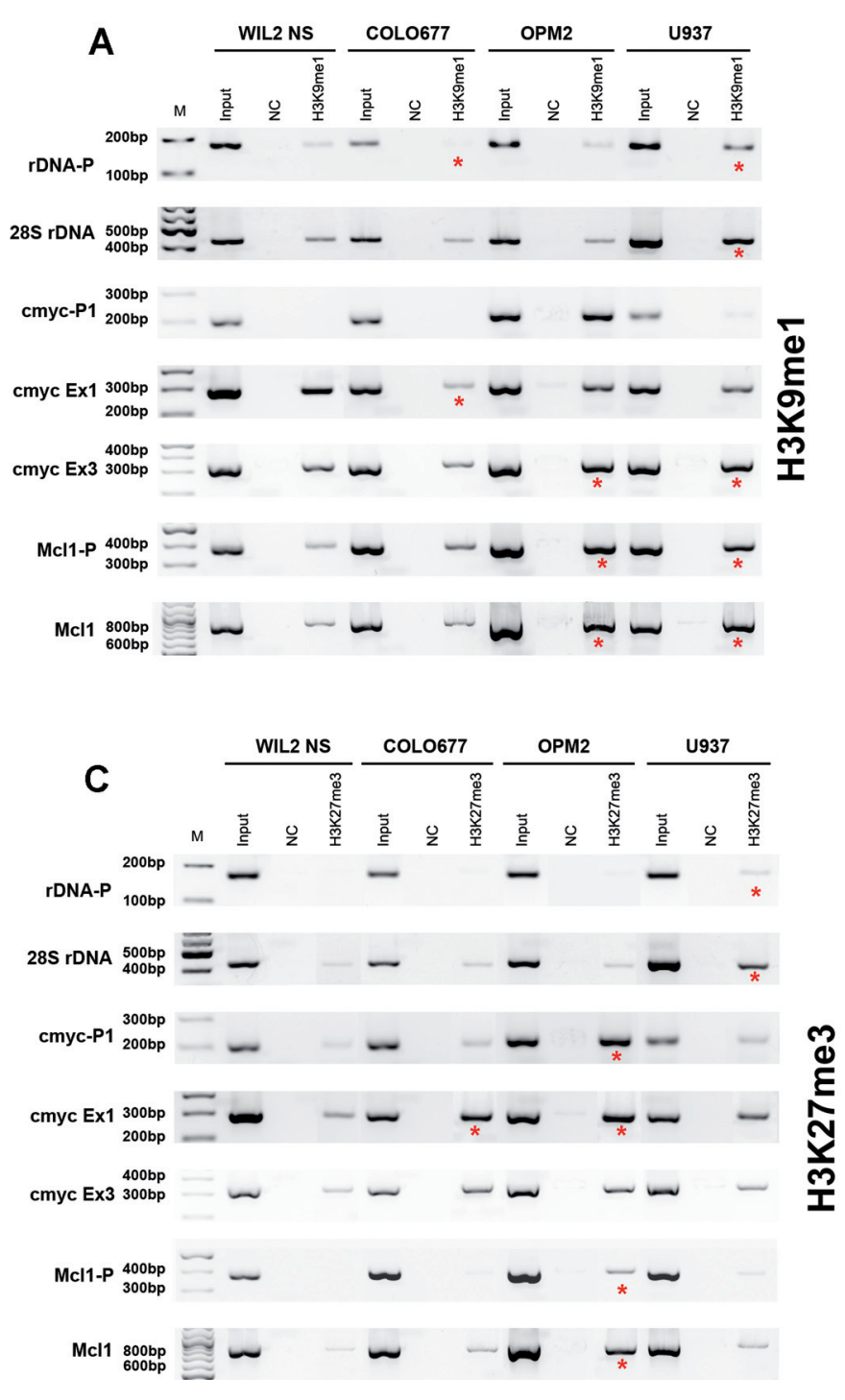

regions, which are specified in Fig. 1. These histone marks were selected because we observed significant differences in the histone signature in MOLP8 and K562 cells as compared with non-malignant WIL2NS cells (see Fig. 3). These additional experiments revealed a distinction in the histone signatures between MM and leukemia cell lines. Taken together, these results revealed a very low level of $\mathrm{H} 3 \mathrm{~K} 9 \mathrm{me} 2$ (compare Figs. $3 \mathrm{D}$ and $6 \mathrm{~B}$ ) in all cell types and genomic regions examined. For the $c-m y c$ and $M c l-1$ proto-oncogenes, we observed heterogeneity in between the levels of $\mathrm{H} 3 \mathrm{~K} 9 \mathrm{me} 1$ in all cell type tested. For example, U937 and OPM2 cells were characterized by pronounced abundance of $\mathrm{H} 3 \mathrm{~K} 9 \mathrm{me} 1$ in all genomic regions analyzed (Fig. 6A), while a very low level of $\mathrm{H} 3 \mathrm{~K} 9 \mathrm{me} 1 \mathrm{was}$ observed in the $c-m y c$ gene in MOLP8 and COLO677 cells (Figs. 3C and 6A). H3K27me3 was relatively high in MOLP8 and OPM 2 cells (Fig. 3F and 6C). Distinctions in histone signature of ribosomal genes were not as pronounced between the cell

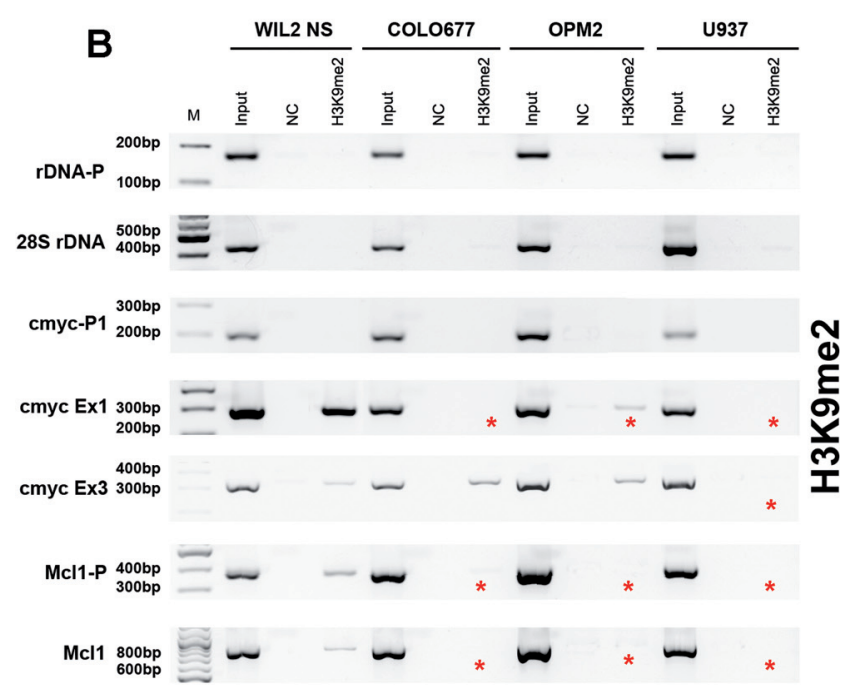

Figure 6. Analysis of selected histone marks in COLO677, OPM2, and U937 cell lines. ChIP-PCR revealed levels of (A) H3K9me1, (B) H3K9me2, and (C) H3K27me3 in MM OPM2 and COLO677 cells and leukemia U937 cells. As control, WIL2NS cells were used. Ribosomal genes, $c-m y c$, and $M c l-1$ proto-oncogenes were evaluated. lines as compared to the cell-type specific histone signature in the proto-oncogenes (Figs. 3 and 6).

Immunofluorescence analysis of nuclear distribution of fibrillarin-positive nucleolar regions, $\mathrm{H} 3 \mathrm{~K} 9 \mathrm{me} 2$, and H3K27me3 in MM, leukemia, and lymphoblastoid cells. Because we analyzed the histone signature of the ribosomal genes, additionally we addressed the pattern of nucleoli. In MM, leukemia, and lymphoblastoid cells, we observed cell type-specific nuclear morphology and arrangement of nucleoli stained by an antibody against the nucleolar protein fibrillarin (Fig. 7Aa). K562 cells were characterized by large nuclei with multiple smaller nucleoli as compared to MOLP8 and WIL2NS cells. Interestingly, vorinostat treatment reduced the area of the nuclei and nucleoli in MOLP8 cells (see quantification in Fig. 7B). MOLP8 cells had large nucleoli in contrast to the leukemia K562 cells (Fig. 7Aa and quantification in Fig. 7Bb). The number of nucleoli was also specific to the cell type (Fig. 7Bc). 
A
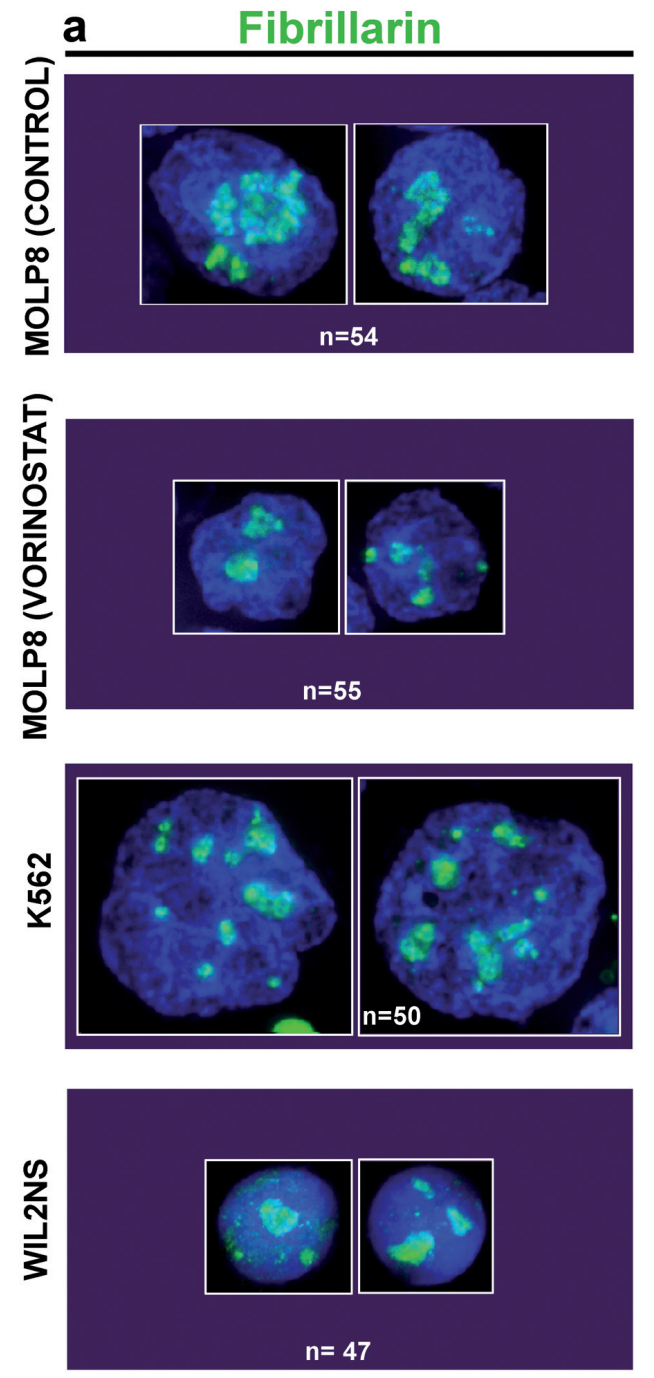

b $\mathrm{H} 3 \mathrm{~K} 9 \mathrm{me} 2$
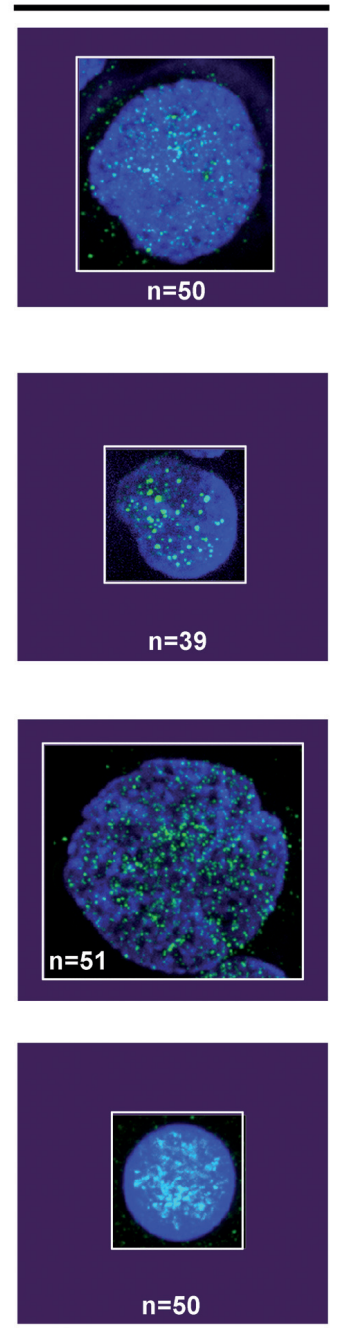
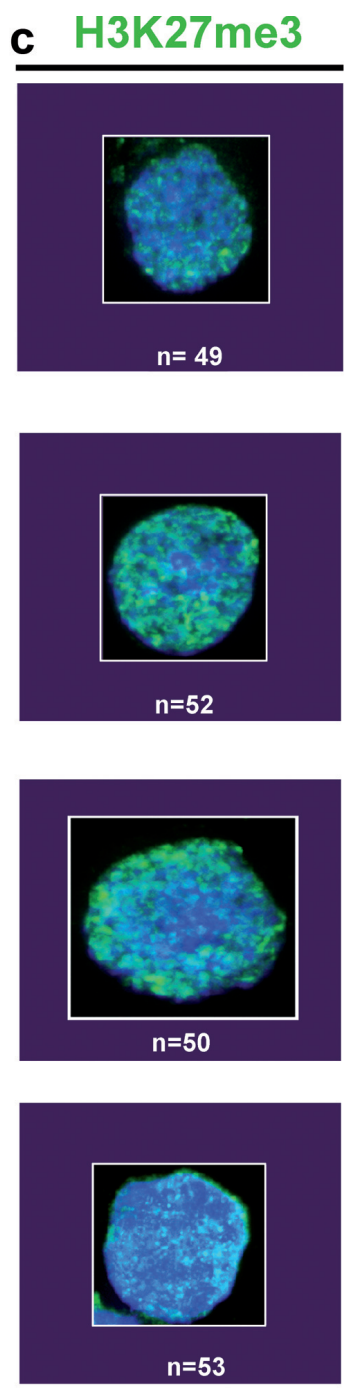

B
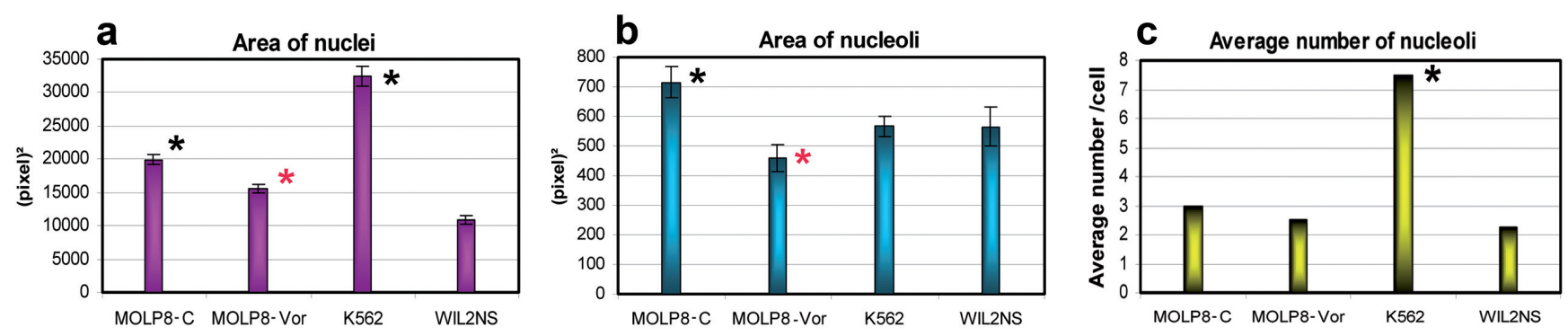

Figure 7. Immunofluorescence analysis of the nuclear distribution of fibrillarin, H3K9me2, and H3K27me3 in MM, leukemia, and lymphoblastoid cells. (Aa) Fibrillarin (green) accumulation in MM MOLP8, leukemia K562, and lymphoblastoid WIL2NS cells was examined. The effect of vorinostat was also tested. Whole cell nuclei were stained with DAPI (blue). (Ab) Nuclear distribution of H3K9me2 in indicated cell types. (Ac) Nuclear distribution of H3K27me3 in indicated cell types. Number of cells analyzed is shown for each individual panel. (Ba) Quantitative analysis of the nuclear area in 2D-mode in MM MOLP8 (number of cells analyzed $n=153)$, leukemia K562 $(n=151)$, and lymphoblastoid WIL2NS ( $n=150)$ cells. The effects of vorinostat were also determined as an average from 146 cells. $(\mathrm{Bb})$ Area of nucleoli in the experimental model. (Bc) Number of nucleoli per cell is shown. Number of cells analyzed in panel $\mathrm{Bb}$ and $\mathrm{Bc}$ is shown in individual panels from section $\mathrm{A}$. The Student's t-test was performed using the Sigma Plot software (version 8.0, Jandel Corporation, USA). Statistically significant differences (at $p \leq 0.05$ ) between control WIL2NS and untreated MOLP8 or K562 cells are shown by black asterisks. Red asterisks denote statistically significant differences (at $p \leq 0.05)$ between MOLP8 control (non-treated) cells and MOLP8 cells treated with vorinostat. 
Immunofluorescence analysis of $\mathrm{H} 3 \mathrm{~K} 9 \mathrm{me} 2$ and $\mathrm{H} 3 \mathrm{~K} 27 \mathrm{me} 3$, which exhibited specific levels in MM and leukemia cells (Fig. $3 \mathrm{D}$ and F), showed a distinct nuclear pattern: H3K9me2 was homogeneously redistributed within the nuclei of $\mathrm{MM}$ and K562 cells; however, in WIL2NS cells, H3K9me2 was not observed at the nuclear periphery (Fig. 7Ab). Vorinostat treatment resulted in more focal arrangement of $\mathrm{H} 3 \mathrm{~K} 9 \mathrm{me} 2$ (Fig. 7Ab). The H3K27me3 nuclear pattern, however, was similar among all cell types studied, even after vorinostat treatment (Fig. 7Ac).

\section{Discussion}

Epigenetic events represent very promising tumor cell therapeutic targets [25]. Epigenetics is concerned with heritable genomic changes but not those related to changes in DNA sequences. Epigenetic events, including activation of transcription factors, post-translational histone modifications, and DNA methylation, can influence gene expression, which is accompanied by activation by specific chromatin-related mechanisms. Novel therapeutic approaches targeting histone modification-related enzymes and DNA methyltransferases (Dnmts) have recently been shown to be clinically significant, especially due to their cytostatic potential.

The discovery of global DNA hypomethylation in human tumors and hypermethylation of $\mathrm{CpG}$ islands in the promoters of tumor suppressor genes initiated new experimental approaches that led to studies on genome-wide DNA methylation, histone signature, and global expression profiles in tumor cells [5]. In addition to changes in DNA methylation, human tumors also have an altered histone signature [5]. In MM cells, we confirmed alterations for several histone marks, including $\mathrm{H} 3 \mathrm{~K} 9 \mathrm{ac}$ and $\mathrm{H} 3 \mathrm{~K} 9 \mathrm{me} 2$, even following treatment with cytostatics [20]. Moreover, the nuclear distribution and nuclear pattern of $\mathrm{H} 3 \mathrm{~K} 9 \mathrm{me} 2$ was altered in MM cells following vorinostat treatment (Fig. 7). Similarly, levels of H3K4me2 and $\mathrm{H} 3 \mathrm{~K} 36 \mathrm{me} 3$ were increased in ribosomal genes after this treatment (Fig. 3A and G). Thus, our experiments support the claim that the epigenetic status of ribosomal genes and the changes in nucleoli composition (see Fig. 7Aa) may be of diagnostic significance for cancer [26].

A tumor cell-specific histone signature was described recently by Jugova et al. [11]. For example, H3K4 methylation was affected by HDACs and Dnmts inhibitors in MM cells, whereas in leukemia cells, H3K9 methylation was altered after biochemical intervention by HDAC and Dnmts inhibition [11]. Compared to normal peripheral blood lymphocytes that were used as controls, clinical MM samples were characterized by increased $\mathrm{H} 3 \mathrm{~K} 9 \mathrm{ac}$ and increased levels of $\mathrm{H} 3 \mathrm{~K} 4 \mathrm{me} 2$, H3K9me2, and HP1a [11]. Moreover, other tumor types exhibited alterations in H4K20me3 or H4K16ac [7]. These data, which were obtained with the help of an animal model, showed that changes in the histone signature appear early during multistage carcinogenesis and are accompanied by hypomethylation of DNA repetitive sequences [7]. Similarly, we demonstrated that MM and leukemia cell populations exhibit a specific histone signature (Figs. 3 and 6). The substitution of the repressive mark H3K9me2 (Fig. 3D) by H3K27me3 (Fig. 3F) in MM cells is of particular interest. This finding confirms our results from another experimental model, demonstrating substitution of centromere cluster-specific $\mathrm{H} 3 \mathrm{~K} 9 \mathrm{me} 3$ by $\mathrm{H} 3 \mathrm{~K} 9 \mathrm{me} 1$ in the absence of histone methyltransferases SUV39h1 and SUV39h2 [27]. The importance of histone methyltransferases was also published in hematological malignancies characterized by chromosome translocations that often involved genes encoding histone acetyltransferases and histone methyltransferases. Moreover, in many cases, gene amplicons consist of sequences that encode histone demethylases, and thus, a role of epigenetic factors in malignant transformation seems to be evident $[5,7]$.

HDACs and histone demethylases are very important anti-tumor targets, and pharmacological agents designed towards epigenetic events are currently clinically very promising. Therefore, we analyzed the effects of vorinostat [10] on the histone signature in MM cells. In addition to histone hyperacetylation (Fig. $3 \mathrm{H}$ ), vorinostat altered the levels of H3K4me2 (Fig. 3A), H3K4me3 (Fig. 3B), H3K9me1 (Fig. 3C), and $\mathrm{H} 3 \mathrm{~K} 36 \mathrm{me} 3$ (Fig. 3G) in selected genomic regions. Thus, the global impact of vorinostat on chromatin plasticity was apparent.

The function of the Mcl-1 protein is critical for the invasiveness of some tumor cells $[28,29]$. Recently, we found that the Mcl-1S variant may serve as an interesting diagnostic factor for MM [13]. The anti-apoptotic activity of Mcl-1 protein, which is a member of the Bcl-2 family, seems to be important in MM cells $[13,18]$. Thus, we tested whether a specific histone signature was responsible for the alternative splicing of Mcl-1 pre-mRNA as documented for other genes and histone marks by Luco et al. and Sims et al. $[17,18]$. Based on our findings, it is possible to suggest that a combination of low $\mathrm{H} 3 \mathrm{~K} 9 \mathrm{me} 1$ and the absence of $\mathrm{H} 3 \mathrm{~K} 9 \mathrm{me} 2$ may be responsible for $\mathrm{Mcl}-1$ alternative splicing. The combination of histone marks that is likely responsible for alternative splicing of particular genes must be very specific, because no changes were detected in the levels of $\mathrm{H} 3 \mathrm{~K} 4 \mathrm{me} 2, \mathrm{H} 3 \mathrm{~K} 9 \mathrm{ac}, \mathrm{H} 3 \mathrm{~K} 27 \mathrm{ac}$, or pan-acetylated histones, whereas $\mathrm{H} 3 \mathrm{~K} 36 \mathrm{me} 3$ and $\mathrm{H} 3 \mathrm{~K} 4 \mathrm{me} 1$ were enriched in the human FGFR2 gene, in which exon IIIb is repressed [17]. Results of these experiments imply that post-translational modifications of histones not only dictate what parts of the genome will be transcriptionally active, but histone signature also affects splicing outcome by the recruitment of splicing regulators via a chromatinbinding proteins $[17,18]$. However, in the case of the $\mathrm{Mcl}-1$ gene in MM cells, rather mutations in the genome can lead to alternative splicing. This notion is documented by the fact that vorinostat, in comparison with non-treated MOLP8 cells, increased $\mathrm{Mcl}-1$ related $\mathrm{H} 3 \mathrm{~K} 9 \mathrm{me} 1$ to the level, observed in WIL2NS cells (Fig. 4C), characterized by an absence of Mcl1S (Fig. 2). However, the Mcl-1S fragment remained stable after vorinostat treatment (Fig. 2). 
It is well known that histone marks are distributed nonrandomly within the genome, and several modifications are enriched specifically in exons relative to their flanking intronic sequences [30]. H3K36me3 marks highly transcribed exons and is more enriched in constitutive exons than in alternatively transcribed ones [31,32]. For some splicing events, the level of $\mathrm{H} 3 \mathrm{~K} 36 \mathrm{me} 3$ is decisive [17]. In addition, H3K4me3 serves to facilitate the competency of pre-mRNA maturation through the bridging of spliceosomal components to $\mathrm{H} 3 \mathrm{~K} 4 \mathrm{me} 3$ via CHD1 [18]. Here, we found that H3K4me3 is increased after vorinostat treatment in MOLP8 cells, mainly in rDNA encoding $28 \mathrm{~S}$ rRNA, the $c-m y c$ promoter, and the $M c l-1$ promoter (Figs. 3B and 4B). Thus, this increase may influence transcriptional activity of the genes studied [33, 34].

In summary, our results demonstrate a specific histone signature in MM and leukemia cells. Furthermore, vorinostat treatment resulted in increased DNA methylation at the promoter of the $c-m y c$ proto-oncogene in MM cells. A very high level of DNA methylation was found in $\mathrm{Mcl}-1$ promoter in leukemia K562 cells when compared with non-malignant cell population (Fig. 5). These results are in agreement with data reported in the early 1980s and summarized more recently by Manel Esteller describing specific changes in DNA methylation in tumor cells [5]. In addition, the epigenetic status of ribosomal genes and changes in nucleoli composition may also be of diagnostic significance $[26,35]$. Interestingly, our data showed that in comparison with $c-m y c$ and $M c l-1$ proto-oncogenes, ribosomal genes are less sensitive to epigenetic instability associated with malignant transformation. Studied proto-oncogenes were in many cases characterized by distinct levels of epigenetic marks, when compared in the various tumor cell lines. This may be associated with tumor-specific genetic background that causes distinct expression levels of particular genomic regions.

Acknowledgments: Our work was supported by Ministry of Education Youth and Sports, project: COST-CZ LD11020. Grant Agency of the Czech Republic, project: P302/10/1022 and P302/12/G157. Support was also derived from European Union, projects: COST action TD09/05; Marie Curie project PIRSES-GA-2010-269156-LCS.

\section{References}

[1] TURNER BM. Reading signals on the nucleosome with a new nomenclature for modified histones. Nat Struct Mol Biol. 2005; 12: 110-2. http: //dx.doi.org/10.1038/nsmb0205-110

[2] KUEHL WM, BERGSAGEL PL. Multiple myeloma: evolving genetic events and host interactions. Nat Rev Cancer. 2002; 2: 175-187. Epub 2002/05/07. doi: 10.1038/nrc746

[3] RAELSON JV, NERVI C, ROSENAUER A, BENEDETTI L, MONCZAK Y, et al. The PML/RAR alpha oncoprotein is a direct molecular target of retinoic acid in acute promyelocytic leukemia cells. Blood. 1996; 88: 2826-2832.

[4] MISTELI T, SOUTOGLOU E. The emerging role of nuclear architecture in DNA repair and genome maintenance. Nat Rev Mol Cell Biol. 2009; 10: 243-254. http: //dx.doi.org/10.1038/ $\underline{\operatorname{nrm} 2651}$
[5] ESTELLER M. Epigenetic changes in cancer. F1000 Biol Rep. 2011; 3: 9. doi: 10.3410/b3-9

[6] FEINBERG AP, VOGELSTEIN B. Hypomethylation distinguishes genes of some human cancers from their normal counterparts. Nature. 1983; 301: 89-92. http: //dx.doi. org/10.1038/301089a0

[7] FRAGA MF, BALLESTAR E, VILLAR-GAREA A, BOIXCHORNET M, ESPADA J, et al. Loss of acetylation at Lys16 and trimethylation at Lys20 of histone $\mathrm{H} 4$ is a common hallmark of human cancer. Nat Genet. 2005; 37: 391-400. http: //dx.doi.org/10.1038/ng1531

[8] KNOEPFLER PS, ZHANG XY, CHENG PF, GAFKEN PR, MCMAHON SB, et al. Myc influences global chromatin structure. EMBO J. 2006; 25: 2723-2734. http: //dx.doi. org/10.1038/sj.emboj.7601152

[9] KNOEPFLER PS. Myc goes global: new tricks for an old oncogene. Cancer Res. 2007; 67: 5061-5063. http: //dx.doi. org/10.1158/0008-5472.CAN-07-0426

[10] MARKS PA, BRESLOW R. Dimethyl sulfoxide to vorinostat: development of this histone deacetylase inhibitor as an anticancer drug. Nat Biotechnol. 2007; 25: 84-90. http: //dx.doi. org/10.1038/nbt1272

[11] JUGOVA A, SUSTACKOVA G, LEGARTOVA S, STIXOVA L, KOZUBEK S, et al. Effects of epigenetic-based anti-cancer drugs in leukemia and multiple myeloma cells. Cell Biol Int. 2011; 35: 1195-1203. http: //dx.doi.org/10.1042/ CBI20100820

[12] LE GOUILL S, PODAR K, AMIOT M, HIDESHIMA T, CHAUHAN D, et al. VEGF induces Mcl-1 up-regulation and protects multiple myeloma cells against apoptosis. Blood. 2004; 104: 2886-2892. http: //dx.doi.org/10.1182/blood-2004-05-1760

[13] LEGARTOVA S, KREJCI J, HARNICAROVA A, HAJEK R, KOZUBEK S, et al. Nuclear topography of the 1q21 genomic region and Mcl-1 protein levels associated with pathophysiology of multiple myeloma. Neoplasma. 2009; 56: 404-413. http: //dx.doi.org/10.4149/neo 2009 $05 \quad 404$

[14] OPFERMAN JT, LETAI A, BEARD C, SORCINELLI MD, ONG CC, et al. Development and maintenance of B and T lymphocytes requires antiapoptotic MCL-1. Nature. 2003; 426: 671-676. http: //dx.doi.org/10.1038/nature02067

[15] BLENCOWE BJ. Alternative splicing: new insights from global analyses. Cell. 2006; 126: 37-47. http: //dx.doi.org/10.1016/ j.cell.2006.06.023

[16] WANG ET, SANDBERG R, LUO S, KHREBTUKOVA I, ZHANG L, et al. Alternative isoform regulation in human tissue transcriptomes. Nature. 2008; 456): 470-476. doi: 10.1038/nature07509

[17] LUCO RF, PAN Q, TOMINAGA K, BLENCOWE BJ, PEREIRA-SMITH OM, et al. Regulation of alternative splicing by histone modifications. Science. 2010; 327: 996-1000. http: //dx.doi.org/10.1126/science. 1184208

[18] SIMS RJ 3RD, MILlHOUSE S, CHEN CF, LEWIS BA, ERDJUMENT-BROMAGE $\mathrm{H}$, et al. Recognition of trimethylated histone $\mathrm{H} 3$ lysine 4 facilitates the recruitment of transcription postinitiation factors and pre-mRNA splicing. Mol Cell. 2007; 28: 665-676. http: //dx.doi.org/10.1016/ j.molcel.2007.11.010 
[19] BARTOVA E, PACHERNIK J, HARNICAROVA A, KOVARIK A, KOVARIKOVA M, et al. Nuclear levels and patterns of histone $\mathrm{H} 3$ modification and $\mathrm{HP} 1$ proteins after inhibition of histone deacetylases. J Cell Sci. 2005; 118: 5035-5046. http: //dx.doi.org/10.1242/jcs.02621

[20] KREJCI J, HARNICAROVA A, STREITOVA D, HAJEK R, POUR L, et al. Epigenetics of multiple myeloma after treatment with cytostatics and gamma radiation. Leuk Res. 2009; 33: 1490-1498. http: //dx.doi.org/10.1016/j.leukres.2009.03.016

[21] COENEN S, PICKERING B, POTTER KN, JOHNSON PW, STEVENSON FK, et al. The relevance of sequence insertions in the Mcl-1 promoter in chronic lymphocytic leukemia and in normal cells. Haematologica. 2005; 90: 1285-1286.

[22] SCHULZE-BERGKAMEN H, BRENNER D, KRUEGER A, SUESS D, FAS SC, et al. Hepatocyte growth factor induces Mcl-1 in primary human hepatocytes and inhibits CD95mediated apoptosis via Akt. Hepatology. 2004; 39: 645-654. http: //dx.doi.org/10.1002/hep.20138

[23] SANTORO R, GRUMMT I. Epigenetic mechanism of rRNA gene silencing: temporal order of NoRC-mediated histone modification, chromatin remodeling, and DNA methylation. Mol Cell Biol. 2005; 25: 2539-2546. doi: 25/7/2539

[24] STRASAK L, BARTOVA E, HARNICAROVA A, GALIOVA G, KREJCI J, et al. H3K9 acetylation and radial chromatin positioning. J Cell Physiol. 2009; 220: 91-101. Epub 2009/02/28. doi: $10.1002 /$ jcp. 21734

[25] ESTELLER M. Cancer Epigenetics for the 21st Century: What's Next? Genes Cancer. 2011; 2: 604-606. http: //dx.doi. org/10.1177/1947601911423096

[26] DERENZINI M, TRERE D, PESSION A, MONTANARO L, SIRRI V, et al. Nucleolar function and size in cancer cells. Am J Pathol. 1998; 152: 1291-1297.

[27] HARNICAROVA HORAKOVA A, GALIOVA G, LEGARTOVA S, KOZUBEK S, MATULA P, et al. Chromocentre integrity and epigenetic marks. J Struct Biol. 2010; 169: 124-133. http: //dx.doi.org/10.1016/j.jsb.2009.09.007

[28] AKGUL C. Mcl-1 is a potential therapeutic target in multiple types of cancer. Cell Mol Life Sci. 2009; 66: 1326-1336. Epub 2008/12/23. doi: 10.1007/s00018-008-8637-6
[29] MAETA Y, TSUJITANI S, MATSUMOTO S, YAMAGUCHI $\mathrm{K}$, TATEBE S, et al. Expression of Mcl-1 and p53 proteins predicts the survival of patients with $\mathrm{T} 3$ gastric carcinoma. Gastric Cancer. 2004; 7: 78-84. http: //dx.doi.org/10.1007/ $\underline{\text { s10120-004-0272-9 }}$

[30] ANDERSSON R, ENROTH S, RADA-IGLESIAS A, WADELIUS C, KOMOROWSKI J. Nucleosomes are well positioned in exons and carry characteristic histone modifications. Genome Res. 2009; 19: 1732-1741. http: //dx.doi. org/10.1101/gr.092353.109

[31] SPIES N, NIELSEN CB, PADGETT RA, BURGE CB. Biased chromatin signatures around polyadenylation sites and exons. Mol Cell. 2009; 36: 245-254. doi: S1097-2765(09)00743-6

[32] KOLASINSKA-ZWIERZ P, DOWN T, LATORRE I, LIU T, LIU XS, et al. Differential chromatin marking of introns and expressed exons by H3K36me3. Nat Genet. 2009; 41: 376-381. http: //dx.doi.org/10.1038/ng.322

[33] SANTOS-ROSA H, SCHNEIDER R, BANNISTER AJ, SHERRIFF J, BERNSTEIN BE, et al. Active genes are tri-methylated at K4 of histone H3. Nature. 2002; 419: 407-411. http://dx.doi. org/10.1038/nature 01080

[34] BERNSTEIN BE, KAMAL M, LINDBLAD-TOH K, BEKIRANOV S, BAILEY DK, et al. Genomic maps and comparative analysis of histone modifications in human and mouse. Cell. 2005; 120: 169-181. http: //dx.doi.org/10.1016/ j.cell.2005.01.001

[35] SIRRI V, URCUQUI-INCHIMA S, ROUSSEL P, HERNANDEZ-VERDUN D. Nucleolus: the fascinating nuclear body. Histochem Cell Biol. 2008; 129: 13-31. Epub 2007/11/30. doi: 10.1007/s00418-007-0359-6.

[36] FINANCSEK I, MIZUMOTO K, MISHIMA Y, MURAMATSU M. Human ribosomal RNA gene: nucleotide sequence of the transcription initiation region and comparison of three mammalian genes. Proc Natl Acad Sci U S A. 1982; 79: 3092-3096. http: //dx.doi.org/10.1073/pnas.79.10.3092

[37] RASKA I, KOBERNA K, MALINSKY J, FIDLEROVA H, MASATA $M$. The nucleolus and transcription of ribosomal genes. Biol Cell. 2004; 96: 579-594. http://dx.doi.org/10.1016/ j.biolcel.2004.04.015 